\title{
Temporal and spatial dynamics of the pelagic microbial food web in an atoll lagoon
}

\author{
J. M. González ${ }^{1}$, J.-P. Torréton ${ }^{2, *}$, P. Dufour ${ }^{3}$, L. Charpy ${ }^{3}$ \\ ${ }^{1}$ Institute of Microbial Studies, La Roza 56, Quintanar de la Sierra, E-09670 Burgos, Spain \\ ${ }^{2}$ Centre ORSTOM de Tahiti, BP 529 Papeete, French Polynesia \\ ${ }^{3}$ ORSTOM, Centre d'Océanologie de Marseille, Traverse de la Batterie des Lions, F-13007 Marseille, France
}

\begin{abstract}
We examined the influence of diurnal cycle, depth, exchange and proximity to land on the dynamics of microbial populations (bacteria, cyanobacteria, nanoplankton, phagotrophic nanoflagellates, ciliates and dinoflagellates) in Tikehau atoll lagoon (French Polynesia). Microbial populations increased over this $15 \mathrm{~d}$ study. Their abundances in the lagoon ranged from 1.2 to $2.6 \times 10^{6}$ bacteria $\mathrm{ml}^{-1}, 1.1$ to $4.0 \times 10^{5}$ cyanobacteria $\mathrm{ml}^{-1}, 200$ to 1090 eukaryotic phytoplankton $\mathrm{ml}^{-1}, 380$ to 1500 phagotrophic nanoflagellates $\mathrm{ml}^{-1}, 0.3$ to 4.0 ciliates $\mathrm{ml}^{-1}$, and 11 to 195 nanodinoflagellates $\mathrm{ml}^{-1}$ Microbial abundances revealed that the intrusion of oceanic water into the lagoon only affected bacterial and cyanobacterial distributions in a narrow band around the lagoon. Grazing rate estimates and population dynamics showed that phagotrophic nanoflagellates were the major grazers of picoplankton (mainly bacteria and cyanobacteria). Cyanobacteria contributed about twice as much as bacteria to this grazed biomass and are therefore supposed to have a higher contribution to the transfer of organic carbon to the upper trophic levels. Hetero- and autotrophic nanoflagellate abundance appeared to be regulated primarily by predators. Ciliates, and perhaps heterotrophic dinoflagellates, appeared to be grazing mostly on nanoplankton, both autotrophic and heterotrophic cells. Autotrophic and heterotrophic dinoflagellate populations increased at net rates comparable to, or even more rapidly than, other microbial communities; this suggests that dinoflagellates also play a significant role in the lagoon microbial foodweb. Additional aspects of the spatial and temporal variability of the microbial foodweb in Tikehau lagoon, as well as the role of grazers and dinoflagellates, are analyzed.
\end{abstract}

KEY WORDS: Atoll lagoon - Microbial food web - Grazing $\cdot$ Bacterioplankton Cyanobacteria $\cdot$ Protists Dinoflagellates · Ciliates - Nanoflagellates

\section{INTRODUCTION}

Marine microbial populations have been the focus of increasing attention during the past 2 decades. Both autotrophic and heterotrophic microorganisms play major roles in pelagic food webs and biogeochemical cycles (Pomeroy 1974, Azam et al. 1983, Cho \& Azam 1990, Sanders et al. 1992). Primary producers, dominated by $<20 \mu \mathrm{m}$ diameter cells, generate organic carbon which will be available to other trophic levels. Bacteria, predominantly $<0.8 \mu \mathrm{m}$ diameter, process a large fraction ( 40 to $60 \%$ ) of this primary

\footnotetext{
- Addressee for correspondence

E-mail: torreton@orstom.orstom.fr
}

production (Azam et al. 1983, Cole et al. 1988, Cho \& Azam 1990)

Both autotrophic and heterotrophic microorganisms are affected by grazers. Heterotrophic nanoflagellates are considered as the key bacterivores in most pelagic systems (Azam et al. 1983, Sherr \& Sherr 1988, Sherr et al. 1989, Sanders et al. 1992). Both ciliates and flagellates have been cited as important phytoplankton consumers (Sherr \& Sherr 1988, Caron et al. 1991, Sherr et al. 1991, Verity 1991). The abundance of grazers is controlled either by the availability of prey or by predation (Kuparinen \& Bjørnsen 1992). Since larger organisms (i.e. zooplankton) can consume protists (Sherr \& Sherr 1988, Stoecker \& Capuzzo 1990, Capriulo et al. 1991), protists constitute a critical link both for 
transferring materials and energy to macroscopic organisms and for channeling organic matter back to microorganisms (Azam et al. 1983, Caron et al. 1985, Sherr \& Sherr 1988).

In spite of the interest in the microbial food webs, our knowledge on interactions and functioning of these communities is scarce. Data on dinoflagellate populations and their role in the microbial food web are rare for most aquatic ecosystems (Lessard \& Swift 1986). More is known on bacteria, cyanobacteria and phytoplankton in atoll lagoon or coral reef waters (Furnas 1990, Ayukai 1992, Torréton \& Dufour 1996a, b) but little has been reported on their trophic interactions with protists within the microbial food web. Very little information is available on the abundance of protists in coral reef waters (Hopkinson et al. 1987, Ayukai 1992, 1995, Sorokin 1994, Ferrier-Pagès \& Gattuso 1998). Protistan grazing remains practically unstudied in coral reef environments (Landry et al. 1984, FerrierPagès \& Gattuso 1998) and to our knowledge there are no reports of abundance, growth rate and grazing activity of protists in atoll lagoons.

Certainly, physical, chemical and biological factors affect the population dynamics of microbial communities in any aquatic ecosystem. Microbes respond quickly to temporal and spatial variations in their environments. Thus, the scale and source of such variability are likely to play a significant role in the long-term equilibrium of an ecosystem (Haury et al. 1978, Steele 1991). Atoll lagoons have been reported as systems showing distinct characteristics relative to the adjacent oceanic waters (Le Borgne et al. 1989, Charpy-Roubaud et al. 1990, Charpy et al. 1997. Pagès et al. 1997), with higher abundances of autotrophic picoplankton (Charpy 1996, Charpy \& Blanchot 1998) and elevated bacterial biomass and activity (Yoshinaga et al. 1991, Torréton \& Dufour 1996a, b) compared to the surrounding oceanic waters. Tikehau lagoon is one example where lagoon waters were stable over several years of investigation (Blanchot et al. 1989. Charpy \& Charpy-Roubaud 1991, Torréton \& Dufour 1996 b) with day-to-day variability in the same range as long-term (seasons) variability.

In this study, the different components of the microbial food web were enumerated and grazing activity of protists on cyanobacteria and heterotrophic bacteria were estimated at various sites in a coral atoll environment (Tikehau lagoon) during November 1992. At that time, a general increase of the abundance of different microbial populations was observed. Sampling every $3 \mathrm{~h}$ along a diurnal cycle and daily sampling during a $15 \mathrm{~d}$ period allowed the estimation and comparison of apparent growth rates of these different populations. Special attention was given to nanoplanktonic microorganisms, i.e. protists, and their role within the pelagic microbial food web.

\section{MATERIALS AND METHODS}

Sampling sites. Tikehau Atoll lies on the western end of the Tuamotu archipelago and has a mean diameter of $25 \mathrm{~km}$ (Fig. 1). The lagoon is connected with the open ocean by 1 main pass, the minimum depth of which is $3.7 \mathrm{~m}$, and by a great number of reef flat spillways, which are only several decimeters deep even at high tide. Average nutrient concentrations are 0.14 , $0.02,0.07,1.26$ and $0.83 \mu \mathrm{M}$ for $\mathrm{PO}_{4}, \mathrm{NO}_{2}, \mathrm{NO}_{3}, \mathrm{NH}_{4}$ and $\mathrm{SiO}_{2}$, respectively, and chlorophyll concentration averages $0.32 \mathrm{\mu g} \mathrm{l}^{-1}$ with $60 \%$ in the 0.7 to $1.0 \mu \mathrm{m}$ fraction (Charpy 1996).

Unless specifically stated, samples were collected from the reference station (Fig. 1) which has been considered as representative of the lagoon (Le Borgne et al. 1989, Charpy \& Charpy-Roubaud 1991, Torréton \& Dufour 1996b). During this study, spatial variability was studied in relation to 3 different questions. (1) The effect of the open ocean on the lagoon was studied by sampling on a transect from a reef flat spillway (main influx of oceanic water) to the main part of the lagoon (H1 to H6) (Fig. 1). (2) The effects of the main island (Tuherahera Motu, the major human colony at the atoll) were studied by sampling at a transect from Tuherahera Motu to the reference station (T1 to T6) (Fig. 1). (3) The effect of depth was also studied. Oceanic samples were collected outside the lagoon close to the main pass (Fig. 1). Temporal variability was studied from 2 points of view: by sampling daily for a 15 d period (D1 to D15), and by sampling frequently during a 24 h study.

Enumeration. Samples for bacterial enumeration were preserved with buffered formalin at a final concentration of $1 \%$. Samples for eukaryotic cell counts were preserved by the Lugol-Formalin decoloration technique described by Sherr et al. (1992). Preserved samples were prepared for counting as soon as possible, generally within $5 \mathrm{~h}$. When necessary, samples mounted on microscope slides were stored frozen at $-20^{\circ} \mathrm{C}$ for a maximum of $2 \mathrm{wk}$. The volumes filtered are commonly used for samples with similar and lower microbial abundances (Kirchman 1993, MacIsaac \& Stockner 1993, Sherr \& Sherr 1993). Bacteria were filtered ( $5 \mathrm{ml}$ ) onto $0.2 \mu \mathrm{m}$ black polycarbonate filters and counted after 4',6-diamidino-2-phenylindole (DAPI) staining (Porter \& Feig 1980). Cyanobacteria were filtered $(5 \mathrm{ml})$ onto $0.2 \mu \mathrm{m}$ polycarbonate filters and enumerated unstained, taking advantage of their orange autofluorescence when excited with blue light (Booth 1987). Bacteria and cyanobacteria were enumerated at a magnification of $1000 \times$. More than 400 bacteria and 200 cyanobacteria were enumerated per sample. Protists were stained with DAPI and collected on $0.8 \mu \mathrm{m}$ and $3 \mu \mathrm{m}$ polycarbonate filters for flagellates 


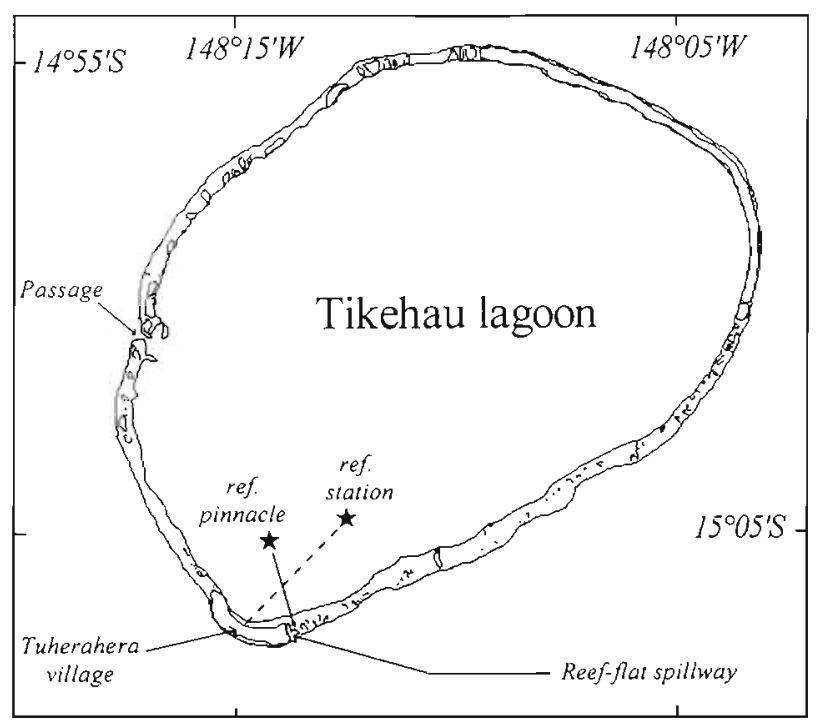

Fig. 1. Tikehau atoll, French Polynesia, showing the location of the reference station. Plain line represents reef-flat spillway-lagoon transect, Stns H1 to H6 are 0,50,100, 200,300 and $3500 \mathrm{~m}$ from the shore. Dotted line shows the villagelagoon transect, Stns T1 to T6 are 5,50,100, 150, 1000 and $4500 \mathrm{~m}$ from the shore

(5 to $10 \mathrm{ml}$ ) and ciliates (up to $125 \mathrm{ml}$ ), respectively. More than 200 flagellates and 30 ciliates were enumerated per filter. Eukaryotic phytoplankton were differentiated by their chlorophyll autofluorescence and enumerated from the same preparations as protists (Booth 1987). Dinoflagellates were enumerated while counting protists. Dinoflagellates were classified according to their autofluorescence under blue excitation light (Lessard \& Swift 1986, Shapiro et al. 1989) as green-fluorescent dinoflagellates, red-fluorescent dinoflagellates (containing chlorophyll) and heterotrophic dinoflagellates (aplastidic cells). Total dinoflagellate numbers were the sum of these 3 categories. All counts were performed with a Leitz Dialux microscope equipped with epifluorescence and the standard UV and blue filter sets. Replicate determinations differed on average by less than $10 \%$ for heterotrophic bacteria, cyanobacteria, flagellates, eukaryotic phytoplankton and dinoflagellates, and by less than $25 \%$ for ciliates.

Grazing experiments. Fluorescently labeled bacteria (FLB) and fluorescently labeled cyanobacteria (FLCB) were prepared for use as tracers for grazing experiments. FLB were made from a marine, rod-shaped isolate (Y isolate; González et al. 1993) from Oregon (USA) coastal waters. Cultures were grown on SWC agar and starved as described by González et al. (1993). Cyanobacteria (CB) were grown on $\mathrm{f} / 2$ medium without silicates, at room temperature (about $15^{\circ} \mathrm{C}$ ) under natural light. Bacteria were harvested by cen- trifugation and stained with 5-([4,6-dichlorotriazin2-yl] amino) fluorescein (DTAF) as described by Sherr et al. (1987). For CB, we followed the modifications for algal cells introduced to the original protocol by Sherr et al. (1991). FLB and FLCB were enumerated in preserved samples onto unstained polycarbonate filters (Sherr et al. 1987). On average, FLB and FLCB had volumes of $0.057 \pm 0.037$ and $0.436 \pm 0.178 \mu^{3}$, respectively, which were in the range of averages for natural bacteria and $\mathrm{CB}$ in our samples. For enumerating FLB and FLCB ingested by protists we first located the protists in DAPI-stained preparations and then we switched from the UV to the blue filter set as described in Sherr et al. (1987). CB autofluorescence and FLCB fluorescence under blue excitation light could be discriminated by color (orange vs green-yellow, respectively) and the shorter duration of $\mathrm{CB}$ autofluorescence than FLCB fluorescence in the preserved samples. All FLB and FLCB ingestion experiments were carried out in $400 \mathrm{ml}$ Whirl Pak bags soaked in $10 \%$ (vol./vol.) $\mathrm{HCl}$ and copiously rinsed with deionized water (Sherr et al. 1987). Experiments were run in duplicate at the original temperature of the water sample. Final concentrations of FLB and FLCB were, on average, 7.4 \pm 3.0 and $7.6 \pm 4.3 \%$ of the in vivo bacterial and cyanobacterial densities, respectively. These FLB and FLCB concentrations can be considered as tracers of natural communities (McManus \& Okubo 1991). For grazing experiments, aliquots of $40 \mathrm{ml}$ for flagellates and $125 \mathrm{ml}$ for ciliates were collected at least twice during the linear portion of the FLB and FLCB uptake curve. Samples were preserved as described above. Per-cell clearance rates ( $\mathrm{nl}$ cell $^{-1} \mathrm{~h}^{-1}$ ) were calculated by dividing the cell-specific ingestion rates of FLB and FLCB by the concentration of FLB or FLCB per nl (Sherr et al. 1987). Rates of community clearance of bacteria and $\mathrm{CB}$ (ingestion rates) were calculated by multiplying the per-cell clearance rates by the total abundance of bacteria or CB per unit of volume and by the abundance of protistan grazers in the samples (Sherr et al. 1987).

Net growth rates. Net growth rates of microbial populations over the diurnal cycle and the $15 \mathrm{~d}$ period of study were estimated by linear regression of the natural logarithm of cell numbers versus time. A minimum of 3 data points were used in the regressions.

\section{RESULTS}

\section{Spatial dynamics}

Depth profiles

Two depth profiles were carried out during this study, one the 4 th day of sampling (referred to as D4), 
when microbial populations were relatively low, and the second one at D13, when microbial abundances were at the maxima reached during this study (see below). Bacterioplankton abundances, as well as cyanobacterial numbers, showed no significant differences throughout the depth profiles (Fig. 2). Bacteria showed little vertical variation around the average value with coefficients of variation of $9 \%$ at D4 and $7 \%$ at D13. Similarly cyanobacteria showed coefficients of variation of $7 \%$ at $\mathrm{D} 4$ and $10 \%$ at D13 around the average value. Eukaryotic phytoplankton and phagotrophic nanoflagellates showed similar numbers between 2.5 and $10 \mathrm{~m}$ depth; however, phagotrophic nanoflagellate abundances were higher than eukaryotic phytoplankton in the remainder of the water column, both at the surface and at the bottom samples (Fig. 2).

\section{Reef-flat spillway - lagoon transect}

Both bacterial and cyanobacterial abundances were highest at the 2 sampling sites closest to the lagoon reference station (H6) (Fig. 3). Bacteria increased from $0.3 \times 10^{6} \mathrm{ml}^{-1}$ at Stn $\mathrm{H} 4$ to $1.2 \times 10^{6} \mathrm{ml}^{-1}$ at $\mathrm{H} 5$. Cyanobacteria increased from $0.02 \times 10^{5}$ to $1.9 \times 10^{5} \mathrm{ml}^{-1}$ at $\mathrm{H} 4$ and $\mathrm{H} 5$, respectively. These increases in bacteria and cyanobacteria were accompanied by increases in phagotrophic nanoflagellate and eukaryotic phytoplankton abundances. Phagotrophic nanoflagellate abundance increased from 450 to $660 \mathrm{ml}^{-1}$ from $\mathrm{H} 4$ to
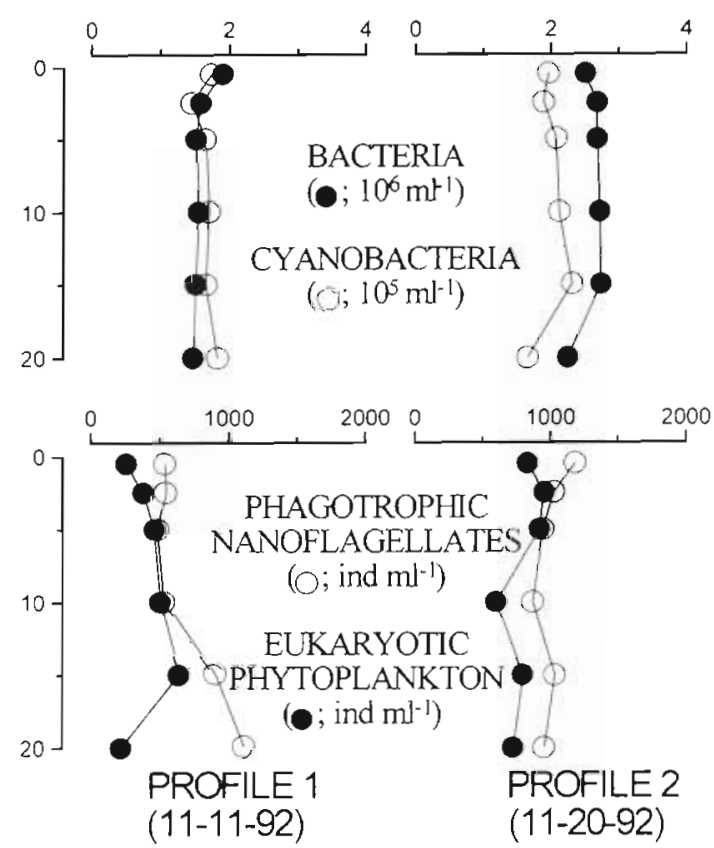

Fig. 2. Microbial abundances at the 2 depth profiles: on Day 4 $(11 / 11 / 92)$ and Day $13(20 / 11 / 92)$. Depth is in meters
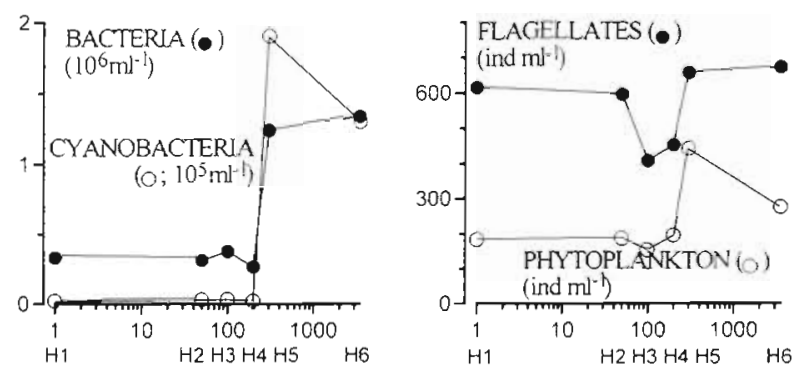

Fig. 3. Microbial abundances at the reef-flat spillway - lagoon transect. Distances from the reef-flat spillway (H1 samples) are in meters

H5, respectively, and the eukaryotic phytoplankton increased from 190 to $440 \mathrm{ml}^{-1}$. Phagotrophic flagellate numbers at $\mathrm{H} 1$ and $\mathrm{H} 2$ (very close to the opening of the reef-flat spillway to the lagoon) showed numbers higher than at $\mathrm{H} 3$ and $\mathrm{H} 4$. Most of these cells, generally 1.5 to $2 \mu \mathrm{m}$ diameter at $\mathrm{H} 1$ and $\mathrm{H} 2$, might be suspended from the sediment at the spillways. At least, a number of them might be autotrophic although red autofluorescence was not detected (probably as a result of their small size and/or relative inactivity); thus, they were classified as heterotrophic cells.

\section{Village-lagoon transect}

Results from this transect are shown in Fig. 4. There was a noticeable decrease of $\mathrm{CB} \mathrm{ml}^{-1}$ from the village to the lagoon reference station (T6). Bacterial abundance decreased between $\mathrm{T} 3$ and $\mathrm{T} 4$. The peak of bac-
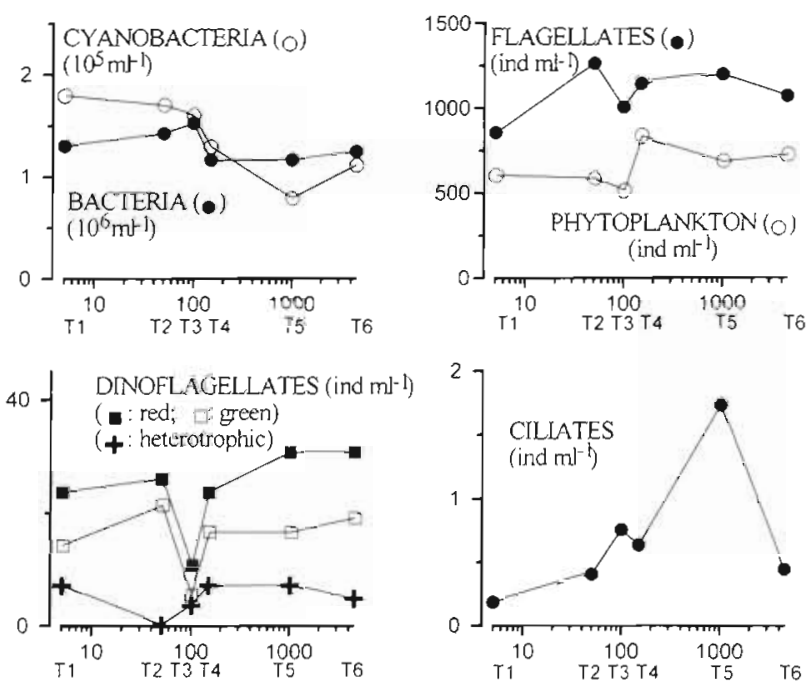

Fig. 4. Microbial abundances at the transect from Tuherahera village to the reference station. Distances from the village are in meters 
terial numbers at $\mathrm{T} 3$ coincided with a minimum in the abundance of phagotrophic nanoflagellates and eukaryotic phytoplankton. Ciliate numbers peaked at T5 concomitantly with high nanoplankton abundances. Autofluorescent dinoflagellates (both red and green) had a minimum at T3 and increased towards the lagoon's interior. Over this transect, heterotrophic dinoflagellate abundance showed smaller fluctuations than autotrophic dinoflagellates.

\section{Temporal dynamics}

Day-to-day evolution

Overall trend. In the lagoon, microbial abundances ranged from 1.2 to $2.6 \times 10^{6}$ bacteria $\mathrm{ml}^{-1}, 1.1$ to $4.0 \times$ $10^{5} \mathrm{CB} \mathrm{ml} \mathrm{m}^{-1}, 200$ to 1090 eukaryotic phytoplankton $\mathrm{ml}^{-1}, 380$ to 1500 phagotrophic nanoflagellates $\mathrm{ml}^{-1}$ and 0.3 to 4.0 ciliates $\mathrm{ml}^{-1}$. Results of the daily sampling showed a simultaneous increase of the pelagic nanoplankton, phagotrophs and phytoplankton in the lagoon (Fig. 5). However, bacterial and cyanobacterial abundances showed a delay ( $3 \mathrm{~d}$ ) with respect to the growth of phagotrophic nanoflagellates and eukaryotic phytoplankton (Fig. 5). Ciliates were the only microbial group that did not experience steady increase throughout the studied period (Fig. 5). Two ciliate abundance peaks were observed, the highest one was on D3 (4 ciliates $\mathrm{ml}^{-1}$ ) and the second one on D10. Dinoflagellates, which belonged mostly to the nanoplankton size-class, ranged from 11 to 195 cells $\mathrm{ml}^{-1}$. Total dinoflagellate abundance generally increased during the study with the exception of a low peak on D11 (Fig. 2). Ten-fold (heterotrophic dinoflagellates) and 20-fold (green- and red-fluorescent dinoflagellates) increases were detected.

Net growth rates. We used the results presented above to estimate the net growth rates of these microbial populations during this study (Table 1). Fig. 5 shows the slopes used for these estimates. No significant differences were found between the net growth rates of cyanobacteria and eukaryotic nanoplankton. Similarly, no significant differences were observed between the net growth rates of bacteria and heterotrophic nanoflagellates. Net growth rate estimates of heterotrophic microorganisms (i.e. bacteria and heterotrophic nanoflagellates) were significantly lower ( $p<0.01$; about 2 -fold) than those of photosynthetic microorganisms (i.e. CB, eukaryotic phytoplankton and fluorescent dinoflagellates). There were no significant differences $(p>0.05)$ in the net growth rates of the dinoflagellate groups distinguished in this study (Table 1). Dinoflagellates (all classes combined) had an overall net growth rate of $0.23 \pm 0.04 \mathrm{~d}^{-1}$ (Table 1).
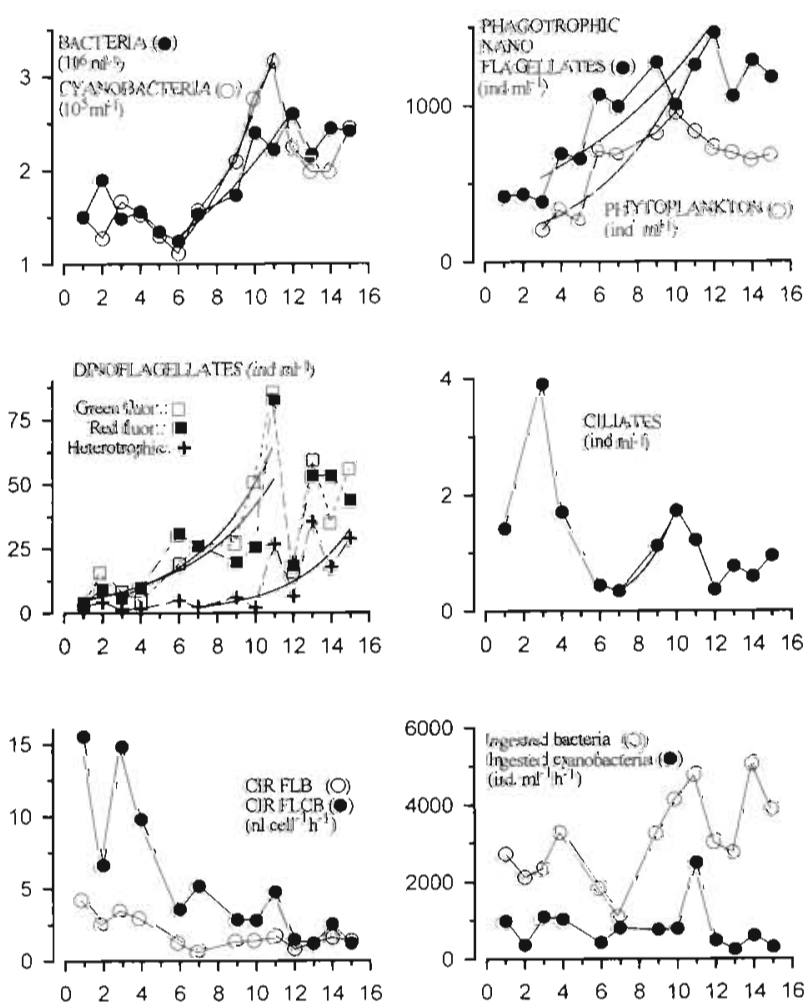

Fig. 5. Microbial abundances during the $15 \mathrm{~d}$ sampling period (Day 1 to Day 15) at Tikehau lagoon reference station. The slopes used for estimating the net growth rates are shown in the plots

Clearance rates. Clearance rates by phagotrophic nanoflagellates on bacteria and $C B$ ranged from 0.8 to 4.5 and 1 to $16 \mathrm{nl}$ flagellate $\mathrm{h}^{-1} \mathrm{~h}^{-1}$, respectively (Fig. 5). Clearance rates by phagotrophic nanoflagellates decreased throughout the period of the study (Fig. 5). Ingestion rates on bacteria (ingested bacteria $\mathrm{ml}^{-1} \mathrm{~h}^{-1}$ ) by phagotrophic nanoflagellates approximately doubled during the sampling period (from 2500 to 5000 ingested bacteria $\mathrm{ml}^{-1} \mathrm{~h}^{-1}$; see Fig. 5). In addition,

Table 1. Net growth rates ( $d^{-t}, S D$ in parentheses) estimated from daily and hourly measurements in Tikehau lagoon waters

\begin{tabular}{|lcc|}
\hline Microbial group & $\begin{array}{c}\text { Day-to-day } \\
\text { sampling }\end{array}$ & $\begin{array}{c}\text { Day/night } \\
\text { sampling }\end{array}$ \\
\hline Bacteria & $0.11(0.02)$ & \\
Cyanobacteria & $0.19(0.02)$ & $3.02(1.41)$ \\
Heterotrophic nanoflagellates & $0.12(0.02)$ & $0.68(0.15)$ \\
Eukaryotic phytoplankton & $0.21(0.04)$ & $0.48(0.22)$ \\
Ciliates & $0.54(0.04)$ & $0.73(0.04)$ \\
Red-fluor. dinoflagellates & $0.23(0.04)$ & $1.38(0.20)$ \\
Green-fluor dinoflagellates & $0.26(0.05)$ & $1.11(0.40)$ \\
Heterotrophic dinoflagellates & $0.33(0.11)$ & $1.83(0.60)$ \\
Total dinoflagellates & $0.23(0.04)$ & $0.99(0.14)$ \\
& & \\
\hline
\end{tabular}


peaks of ingestion were related to peaks in bacterial numbers. Ingestion of $\mathrm{CB}$ by phagotrophic nanoflagellates showed a sharp peak on D11 (2500 ingested CB $\mathrm{ml}^{-1} \mathrm{~h}^{-1}$ ). This peak coincided with the maximum number of $C B$ detected during this study. During the remaining of the studied period, ingestion rates of $C B$ by phagotrophic nanoflagellates oscillated between 400 and 800 ingested CB ml-1 $\mathrm{h}^{-1}$.

\section{Day/night cycle}

Overall trend. We investigated diurnal variations in microbial populations on D10 and D11. Results of this day/night cycle are reported in Fig. 6. Cyanobacterial abundances had a maximum at around midnight. Bacterial abundance showed no consistent trend, with a coefficient of variation of $7 \%$ around the daily average. The number of phagotrophic nanoflagellates increased during daytime (from about 09:00 h), and decreased from midnight to about 09:00 h. Numbers of eukaryotic phytoplankton $\mathrm{ml}^{-1}$ increased during daytime from 09:00 to 18:00 h. Grazing pressure, probably by ciliates, looked more intense early in the morning 106:00 to $09: 00 \mathrm{~h}$ ) as judged by the peaks in ciliate abundances. A decrease of ciliates $\mathrm{ml}^{-1}$ was observed early
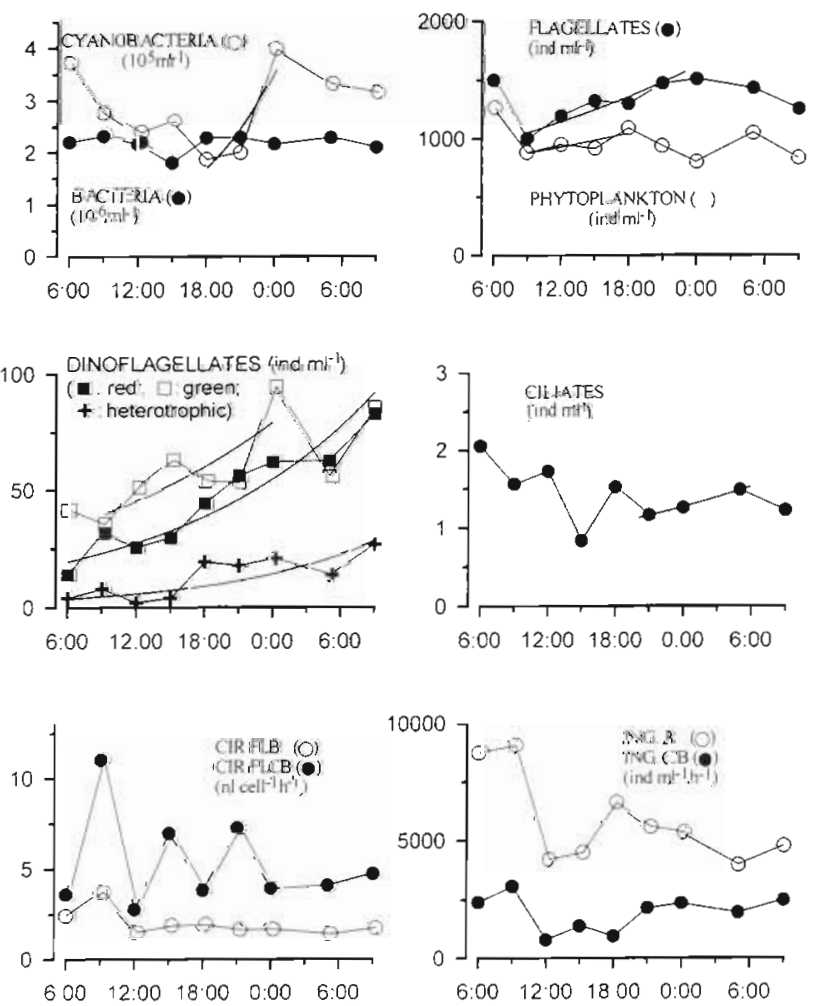

Fig. 6. Microbial abundances during a $24 \mathrm{~h}$ sampling period at Tikehau lagoon reference station. The slopes used for estimating the net growth rates are shown in the plots in the morning. Generally, peaks of ciliate abundances appeared to be inverse to those of heterotrophic nanoflagellates and autotrophic nanophytoplankton numbers $\mathrm{ml}^{-1}$ (Fig. 6). Both green- and red-fluorescent dinoflagellate abundances showed an increase during the sampling period. For red-fluorescent dinoflagellates, that increase continued until midnight. Heterotrophic dinoflagellate number increased during the afternoon and remained constant during the rest of the day/night cycle (Fig. 6).

Net growth rates. Net growth rates estimated from the increases in abundance of the studied microbial populations during a $24 \mathrm{~h}$ period were much higher than those obtained from our $15 \mathrm{~d}$ sampling period (Table 1). We were unable to estimate net growth rates for bacteria since bacterial abundance showed no significant trend during this $24 \mathrm{~h}$ period. CB had a net growth rate (Table 1) around 15 times higher than our estimate from the $15 \mathrm{~d}$ period. The net growth rate of phagotrophic nanoflagellates during the day/night cycle was about 5 times the estimate shown above from day-to-day samples (Table 1). The estimate for eukaryotic phytoplankton is more than 2 -fold our estimate of net growth rate from the $15 \mathrm{~d}$ period. Net growth rates of dinoflagellates, estimated from their increases in numbers during the $24 \mathrm{~h}$ study (Fig. 6, Table 1), were about 6 -fold (for red-fluorescent dinoflagellates), 4-fold (for green-fluorescent dinoflagellates), 5-fold (for heterotrophic dinoflagellates), and 4 -fold (for the total number of dinoflagellates) the values reported above from the $15 \mathrm{~d}$ study. No significant differences were observed between the net growth rates estimated for the different dinoflagellate populations. Net growth rates of autofluorescent dinoflagellates (both green and red) were higher than the estimates of eukaryotic nanoplankton, both auto- and heterotrophs.

\section{DISCUSSION}

In this study, we did not count Prochlorococcus, Their dim autofluorescence prevents quantitative enumeration by epifluorescence microscopy. As suggested by recent reports, Prochlorococcus abundance could significantly bias bacterial and phytoplankton counts. However, while Prochlorococcus dominates picophytoplankton in subtropical (Campbell et al. 1997) and tropical waters of the Pacific Ocean (Blanchot \& Rodier 1996), most atoll lagoons switch to a Synechococcus dominance (Charpy \& Blanchot 1998). In atoll lagoons Synechococcus and Prochlorococcus abundances are inversely related and in 3 Tuamotu atoll lagoons where Synechococcus abundances are in the same range as at Tikehau ( 1 to $3 \times 10^{5}$ cells $\mathrm{ml}^{-1}$ ), Prochlorococcus 
abundances are 4 - to 20-fold lower than Synechococcus numbers (Charpy \& Blanchot 1998). Prochlorococcus are likely counted as heterotrophic bacteria using epifluorescence microscopy (Campbell et al. 1994). Based on the characteristics and picoplankton abundances at Tikehau atoll lagoon, Prochlorococcus would only contribute 0.5 to $2.5 \%$ of bacterial counts in Tikehau lagoon. In addition, results from 10 Tuamotu atoll lagoons (Charpy \& Blanchot 1998) showed Prochlorococcus abundances between 0.1 and $8.3 \%$ of bacterial counts using epifluorescence microscopy. This is within the coefficient of variation for bacterial counts (see 'Materials and methods').

\section{Spatial distribution}

Tikehau lagoon has been reported to be a stable ecosystem (Blanchot et al. 1989, Charpy \& CharpyRoubaud 1991, Torréton \& Dufour 1996b) as well as to show characteristics distinctive from those of the adjacent oceanic waters. Results from the village-lagoon and the reef-flat spillway-lagoon transects suggested the existence of spatial variability at Tikehau lagoon. However, these effects were very restricted. The village affected only a narrow area around the main island at Tikehau lagoon (Fig. 4), and the effects of the ocean on the microbial populations were only significant within $300 \mathrm{~m}$ of the reef-flat opening to the lagoon (Fig. 3). In addition, the $300 \mathrm{~m}$ zone under oceanic influence is quite shallow, which let us deduce that only an insignificant volume of the lagoon is directly affected by the ocean. During our study period, the inflow speed was $11.2 \mathrm{~cm} \mathrm{~s}^{-1}$, very close to the annual average into this spillway (11 $\mathrm{cm} \mathrm{s}^{-1}$; Lenhardt 1991), which makes these results comparable to other studies. Similar influences of the ocean on this lagoon's food web have also been demonstrated for zooplankton (Le Borgne et al. 1989).

During our experiments, we did not estimate directly grazing on autotrophic or heterotrophic nanoplankton. However, Gasol (1994) observed that the relationships between bacteria and phagotrophic flagellate abundances can be used to figure out which mechanisms (i.e. top-down vs bottom-up) likely control phagotrophic nanoflagellate abundance in aquatic ecosystems. Applying his framework to our data from Tikehau lagoon showed that phagotrophic nanoflagellates are probably controlled by predation as most of the data points are located at the right of the Maximum Attainable Abundance line (MAA; Fig. 7). Four samples (7.7\% of cases) represented a peculiarity (the 4 data points between the MAA and MRA lines; see Fig. 7); these exceptions were obtained from the surroundings of the lagoon (3 reef-flat spillway samples [H1, H2, H3]

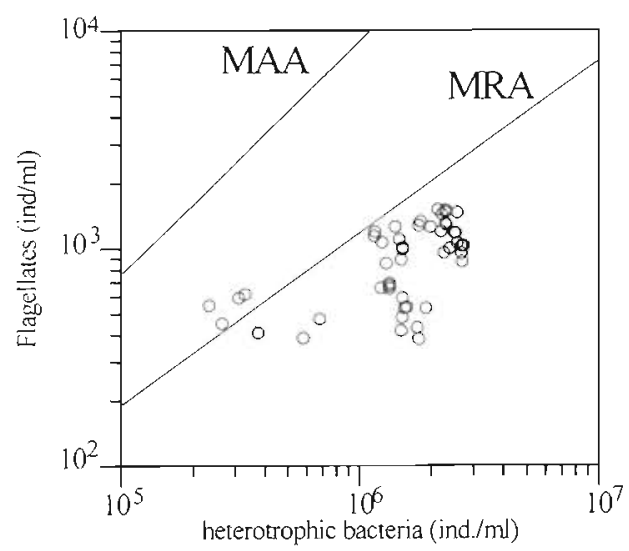

Fig. 7. Plot of our data from Tikehau lagoon using the framework proposed by Gasol (1994). The 4 data points between the MAA (maximum attainable abundance) and MRA (mean realized abundance) lines were obtained from samples at the surroundings of the lagoon ( 3 reef-flat spillway samples [H1, $\mathrm{H} 2, \mathrm{H} 3$ ] and 1 sample at the passage)

and 1 sample at the passage), zones where the ocean actually influences lagoon waters. If both bacteria and $\mathrm{CB}$ are considered as picoplanktonic prey for nanoflagellates, the data points plotted in Fig. 7 would be moved towards the right, which would corroborate the above deduction. Thus, in Tikehau lagoon, nanoplankton appeared to be primarily regulated by top-down control (i.e. grazing by predators, for example ciliates)

\section{Temporal dynamics}

Day-to-day patterns

Overall trend. The abundances of picoplankton and nanoplankton reported in this study were in the range cited for marine waters (Cho \& Azam 1990, Furnas 1990, Capriulo et al. 1991), and ciliate numbers found during this study are in agreement with those reported for coastal waters and the open ocean by several authors (Stoecker et al. 1989, Beers et al. 1992, SimeNgando et al. 1992). Very few studies have addressed the entire microbial community in coral reef waters Bacteria (1.2 to $\left.2.6 \times 10^{6} \mathrm{ml}^{-1}\right)$, cyanobacteria ( 1.1 to 4.0 $\left.\times 10^{5} \mathrm{ml}^{-1}\right)$ and ciliates ( 0.3 to 4.0 ciliates $\left.\mathrm{ml}^{-1}\right)$ were on average 3 -, 12 - and 6 -fold more abundant in Tikehau lagoon than in waters overlying a coral reef in Bora Bay, Japan (Ferrier-Pagès \& Gattuso 1998), while HNF (380 to $1500 \mathrm{ml}^{-1}$ ), and eukaryotic phytoplankton (200 to $1090 \mathrm{ml}^{-1}$ ) were in the same range. Numbers of dinoflagellates (11 to $195 \mathrm{ml}^{-1}$ ) were similar to those reported in different ecosystems (Furnas 1990, Hansen 1992). On average, bacteria and HNF were 2 -fold more abundant, and ciliates showed 2 -fold lower numbers, 
than in waters overlying Lizard Island reef, Australia (Sorokin 1994). Microbial numbers vary seasonally and among stations at Lizard Island reef (the richest) and Myrmidon reef, Australia (Ayukai 1995). In Tikehau lagoon, bacteria, cyanobacteria, HNF and ciliates were roughly 2 - to 20 -, 10 - to $300-, 0.6$ - to 20 - and 30 - to 200 fold, respectively, those estimated over Lizard Island and Myrmidon reefs. HNF, ciliate and heterotrophic dinoflagellate numbers were similar to those reported in Kaneohe Bay (Landry et al. 1984), while bacteria and cyanobacteria were about 2 -fold more abundant. The relative richness of bacterioplankton. in Tikehau lagoon compared to water overlying coral reefs (Torréton \& Dufour 1996b) seems therefore to hold for other planktonic components.

From our data, daily sampling showed that the growth of bacteria and CB was delayed ( 3 d) compared to the growth of phagotrophic nanoflagellates and eukaryotic phytoplankton (Fig. 5). On D6, bacterial and cyanobacterial growth might have been facilitated by a decrease in clearance rates by phagotrophic nanoflagellates on bacteria and CB (Fig. 5). The highest peak of ciliates on D3 (4 ciliates $\mathrm{ml}^{-1}$ ) could have led to phagotrophic nanoflagellate and eukaryotic nanophytoplankton minima on that date. Small peaks of bacteria and CB concentrations were also observed on D2 or D3, respectively, and were likely favored by the weak abundance of phagotrophs (Fig. 5). The second ciliate peak was on D10 and might have been a consequence of high peaks of both pico- and nanoplankton densities (Fig. 5).

Net growth rates. Net growth rate of bacterioplankton determined from exponential regression of bacterial numbers versus time from D6 to D12 $(0.11 \pm 0.02$ $\mathrm{d}^{-1}$; Table 1 ) represents $70 \%$ of gross growth rates estimated from $T d R$ and Leu incorporation at the same period (respectively, $0.16 \pm 0.05$ and $0.16 \pm 0.04 \mathrm{~d}^{-1}$; Torréton \& Dufour 1996b). The net growth rate of cyanobacteria $\left(0.19 \pm 0.02 \mathrm{~d}^{-1}\right.$; Table 1$)$ was 7 -fold lower than average gross growth rate value of picoplankton $<1 \mu \mathrm{m}$ in Tikehau lagoon. (1.32 $\mathrm{d}^{-1}$; Charpy 1996). As grazing activity on bacteria and cyanobacteria occurred even during steady increases in their abundance, net growth rates obtained from day-to-day increases are in rough agreement with gross growth rates. Net growth rates for $\operatorname{HNF}\left(0.12 \pm 0.02 \mathrm{~d}^{-1}\right)$ and ciliates $\left(0.54 \pm 0.04 \mathrm{~d}^{-1}\right)$ are 0.06 - to 0.1 - and 0.6 - to 0.8 fold those determined in Bora Bay reef waters (FerrierPagès \& Gattuso 1998, excluding ciliates' null growth rate in their third growth experiment).

In our study, net growth rate estimates of heterotrophic microorganisms (i.e. bacteria and phagotrophic nanoflagellates) were shown to be signiticantly lower ( $p<0.01$; about 2 -fold) than those of photosynthetic microorganisms (i.e. CB and eukaryotic phytoplank- ton). This suggests that primary producers (both picoand nanophytoplankton) may play an important role regulating the heterotrophic compartments of the microbial food web in Tikehau lagoon during the studied period. Measured dinoflagellate (all classes combined) net growth rate is comparable to those obtained for photosynthetic microorganisms (i.e. CB and eukaryotic phytoplankton) (Table 1); this suggests that the role of dinoflagellates may be comparable to the other microbial communities in Tikehau lagoon, at least duning the studied period.

Clearance rates. Our estimates of clearance rates are in agreement with those reported for heterotrophic nanoflagellates on bacterioplankton (Sherr et al. 1987 , Capriulo et al. 1991) and CB (Caron et al. 1991). Clearance rates by phagotrophic nanoflagellates decreased throughout this study corresponding to an increase in microbial abundances (Fig. 5); this suggests that increased concentrations of prey might lead to lower clearance rates. Thus, as prey number increases, the volume of water processed by a nanoflagellate declines to obtain a similar number of prey. We estimated that bacteria and CB grazed by ciliates represented, on average, $1.63 \pm 0.99$ and $3.26 \pm 2.70 \%$ of those grazed by phagotrophic nanoflagellates, respectively. Some authors (Fenchel 1984, Sherr \& Sherr 1988) have reported that ciliates cannot efficiently graze on bacterial-size prey (including $\mathrm{CB}$ ) at the concentrations present in nature (about $10^{6}$ bacteria $\mathrm{ml}^{-1}$ ). Thus, ciliates could be preferentially consuming nanoplankton which is larger in size (Sherr \& Sherr 1988). During our counts, ciliates were commonly observed with chlorophyll-containing nanoplanktonic prey. Although phytoplankton might be the preferred food source for ciliates, phagotrophic nanoflagellates in the same size range could be an alternative or complementary prey for ciliates (Verity 1991). This is supported by the observation (see above) that nanoplankton abundance appeared to be controlled by top-down mechanisms, probably by ciliate grazing, in Tikehau lagoon.

\section{Day/night cycle}

Overall trend. During the diurnal cycle experiment some patterns appear to be in agreement with each other. In our experiments, CB abundances had a maximum at around midnight (see below). A reduction during daytime could be the result of intense grazing by the actively growing population of heterotrophic nanoflagellates. These results are in agreement with those of Ayukai (1992), who showed similar diel fluctuations for CB. Bacterioplankton abundance was approximately constant during the day/night cycle which is in agreement with the stability of the bacterial commu- 
nity during several studies in Tikehau lagoon and the low growth rate of this community (Torréton \& Dufour 1996b). Phagotrophic nanoflagellate abundance increased during the day and decreased from midnight to about 09:00 h. An elevated grazing pressure by larger organisms (i.e. ciliates) in the morning (from midnight) could be responsible for that reduction in flagellate numbers; this was supported by a maximum of ciliates $\mathrm{ml}^{-1}$ observed early in the morning. Indeed, ciliate abundances often showed inverse peaks to those of phagotrophic nanoflagellates and autotrophic nanophytoplankton. Again, this suggests that the abundance of both communities (heterotrophic and autotrophic nanoplankton) might be mainly controlled by ciliates.

Net growth rates. Bacterial abundance decreased slightly during this $24 \mathrm{~h}$ period; this might be a result of an intense grazing pressure mainly by phagotrophic nanoflagellates. $C B$ had a net growth rate $\left(3 \mathrm{~d}^{-1}\right.$; Table 1) around 15 times greater than our estimate from the $15 \mathrm{~d}$ period; this is in the upper limit reported for CB (Synechococcus-like) in coral reef lagoons (Furnas 1990, Ayukai 1992, Ferrier-Pagès \& Gattuso 1998). This extremely high value might be the result of synchronous division (Ayukai 1992) during the night since this result is not supported by ${ }^{14} \mathrm{C}$-primary production estimates (Charpy 1996). Our estimate of net growth rate for phagotrophic nanoflagellates was similar to that reported by Andersen \& Sorensen (1986) calculated from a similar set of experiments in a eutrophic coastal environment and was 0.3- to 0.6-fold less than that determined in Bora Bay reef waters (Ferrier-Pagès \& Gattuso 1998). The estimate for eukaryotic phytoplankton is more than 2-fold our estimate of net growth rate from the $15 \mathrm{~d}$ period (Table 1) but it is in the range reported by other authors for tropical phytoplankton assemblages (Furnas 1990). Net growth rate for ciliates was similar to that reported by Ferrier-Pagès \& Gattuso (1998) in Bora Bay reef water. Our estimates of growth rates for heterotrophic dinoflagellates were around the upper limit reported in the literature (Lessard \& Swift 1986, Furnas 1990, Hansen 1992, Strom \& Buskey 1993), and they were comparable to those of other microbial communities in Tikehau lagoon.

\section{Temporal variability}

Microbial populations experienced an overall net increase in numbers during this study. The large differences found between long-term (several days) and short-term (several hours) estimates of net growth rates are additional evidence in favor of the existence of active regulatory mechanisms of prey populations in Tikehau lagoon. With regard to temporal fluctuations, and provided that our single diel cycle was typical of diel evolution in Tikehau lagoon, our data showed that day-to-day fluctuations represented a major source of temporal variability for the communities studied herein, at least during this study. Wind might also have significant effects on day-to-day fluctuations, at least on bacterioplankton abundance (Torréton \& Dufour 1996b) and likely on other planktonic groups, by releasing nutrients from the upper sediments of the lagoon. During this study, there were calm and windy intervals but no wind speed record is available from the studied period.

\section{Importance of dinoflagellates}

Dinoflagellates are discussed separately since very little is known about their trophic interactions with other microbial communities. We observed increases in dinoflagellate abundances during this $15 \mathrm{~d}$ study (Fig. 5). Significant fluctuations of dinoflagellate abundances were also associated with diel effects and spatial variables (Fig. 6). Our results showed that dinoflagellates can grow at rates similar to those of other components of the microbial food web. This contrasts with results of Hansen (1992), who reported that heterotrophic dinoflagellates had lower growth rates than their possible competitors. Differences between longterm (several days) growth estimates and the shortterm (several hours) estimates suggest that dinoflagellate abundances, as in the other microbial groups, were effectively regulated in Tikehau lagoon. The role of nanodinoflagellates in pelagic ecosystems is still uncertain. For instance, the differences in their fluorescence (green or red autofluorescence, or lacking autofluorescence) are certainly due to differences in pigment composition, but, as far as we know, the role of those pigments in their physiology and ecology is not well understood (Shapiro et al. 1989). From our results and growth rate estimates, autotrophic nanodinoflagellates might successfully compete with other eukaryotic phytoplankton. Hansen (1992) reported that small $(<20 \mu \mathrm{m})$ heterotrophic dinoflagellates compete with ciliates for nanoplanktonic prey; in this way, heterotrophic dinoflagellates might contribute to regulating nanoplanktonic populations (both autotrophic and heterotrophic) in Tikehau lagoon. Furthermore, heterotrophic dinoflagellates have been reported to be capable of bacterial ingestion although this is probably insignificant when compared with the importance of other heterotrophic nanoflagellates. Our results, and those by other authors (Hansen 1991, 1992), showed that higher densities of autotrophic and heterotrophic dinoflagellates are found in association with high abundances of other nanoplanktonic organisms. In 
addition, in this study, net growth rates were estimated from natural communities without previous incubation or without the use of cultured isolates; this supports the idea that, in nature, nanodinoflagellates can actually show higher growth rates than previously suggested (Furnas 1990, Hansen 1992). The above suggests dinoflagellates might play a more important role in Tikehau lagoon than suspected from previous studies on dinoflagellate ecology in marine ecosystems.

\section{Fate of heterotrophic and autotrophic bacterial production in the lagoon}

In Tikehau lagoon, heterotrophic nanoflagellates consumed on average $( \pm \mathrm{SE}) 3.86 \pm 0.39 \times 10^{6}$ bacteria $\mathrm{l}^{-1} \mathrm{~h}^{-1}$ and $1.20 \pm 0.16 \times 10^{6}$ cyanobacteria $\mathrm{l}^{-1} \mathrm{~h}^{-1}$ during this study $(n=26)$. These values represent 27 and $12 \%$, respectively, of bacterial and cyanobacterial production of $12.7 \times 10^{6}$ bacteria $\mathrm{l}^{-1} \mathrm{~h}^{-1}$ (Torréton \& Dufour $1996 \mathrm{~b}$ ) and $10.3 \times 10^{6}$ cyanobacteria $\mathrm{I}^{-1} \mathrm{~h}^{-1}$ (Charpy 1996; assuming growth rate of cyanobacteria to be similar to that of the $<1 \mu \mathrm{m}$ fraction). Ciliates consumed on average $5.45 \pm 0.64 \times 10^{4}$ bacteria $\mathrm{l}^{-\mathrm{t}} \mathrm{h}^{-1}$ and $3.23 \pm$ $0.60 \times 10^{4}$ cyanobacteria $\mathrm{l}^{-1} \mathrm{~h}^{-1}$ during this study $(\mathrm{n}=$ 24 ). This represents 0.4 and $0.3 \%$, respectively, of bacterial and cyanobacterial production. Grazing by ciliates appears to have a minor impact on bacterial and cyanobacterial production. Reported consumption rates range between 5 and $430 \%$ of bacterial production (see review by Solic \& Krstulovic 1994). Discrimination between natural prey and heat-killed prey could explain some of these differences. González et al. (1993) reported that actual grazing rates by HNF could be underestimated by at least $50 \%$ by measuring grazing on FLB if there is $1 \%$ of motile bacteria in the bacterial assemblage. High rates of lysis by viruses (Suttle 1994) could also explain some of the differences observed between bacterial or cyanobacterial production and grazing by protists. Based on $20 \mathrm{fg} C$ per bacterial cell (Lee \& Fuhrman 1987) and $107 \mathrm{fg} C$ per cyanobacterial cell (Charpy 1996), HNF grazing rates on bacteria and cyanobacteria would be equivalent to $1.85 \pm 0.19$ and $3.09 \pm 0.40 \mu \mathrm{g} \mathrm{C} \mathrm{l}^{-1} \mathrm{~d}^{-1}$, respectively. If we consider a possible bias on grazing determinations similar for cyanobacteria and bacteria, this would signify that cyanobacteria contribute almost twice as much as bacteria to the transfer of organic carbon to the upper trophic levels through HNF grazing

\section{CONCLUSION}

In the present study, the spatial and temporal variability of the microbial food web in Tikehau lagoon has been analyzed. An active microbial food web explained the high microbial standing stocks observed at Tikehau lagoon, as well as its differential characteristics when compared to the surrounding oceanic waters. However, the direct influence of the ocean on the lagoon's microbial abundances was restricted and, generally, insignificant. Cyanobacteria and bacteria were at the base of the Tikehau microbial food web; both bacteria and cyanobacteria were mainly preyed upon by nanoplankton. Ciliate predation had a minor effect on bacteria and cyanobacteria. During this study, nanoplankton numbers, both heterotrophic and autotrophic, appeared to be regulated by their predators (top-down control); ciliates and heterotrophic nanodinoflagellates might be controlling nanoplankton abundance. Dinoflagellates, mainly in the nanoplankton range, experienced increases in numbers during the studied period, and they are proposed as a potentially significant microbial community in Tikehau lagoon. During this study, both spatial and temporal fluctuations of the studied microbial communities were observed. A long-term microbial stability in Tikehau lagoon waters has been previously reported (Blanchot et al. 1989, Charpy \& Charpy-Roubaud 1991, Torréton \& Dufour 1996b) which can be explained by the existence of regulatory mechanisms within the microbial food web in Tikehau lagoon. Further aspects of the Tikehau microbial food web will be published elsewhere.

Acknowledgements. This work was supported by grants from ORSTOM on the CYEL program and PNRCO (Programme National sur les Récifs Coralliens, INSU-ORSTOM). We thank $\mathrm{J}$. T. Hollibaugh for extensive comments on an early version of this work. We are grateful to 4 anonymous reviewers for helpful comments on the manuscript.

\section{LITERATURE CITED}

Andersen P, Sorensen HM (1986) Population dynamics and trophic coupling in pelagic microorganisms in eutrophic coastal waters. Mar Ecol Prog Ser 33:99-109

Ayukai T (1992) Picoplankton dynamics in Davies Reef lagoon, the Great Barrier Reef, Australia. J Plankton Res 14:1593-1606

Ayukai T (1995) Retention of phytoplankton and planktonic microbes on coral reefs within the Great Barrier Reef, Australia. Coral Reefs 14:141-147

Azam F, Fenchel T, Field JG, Gray JS, Meyer-Reil LA, Thingstad $F$ (1983) The ecological role of water-column microbes in the sea. Mar Ecol Prog Ser 10:257-263

Beers JR, Reid FMH, Steward GL (1992) Seasonal abundance of the microplankton populations in the North Pacific central gyre. Deep-Sea Res 29:227-245

Blanchot J, Charpy L, Le Borgne R (1989) Size composition of particulate organic matter in the lagoon of Tikehau atoll (Tuamotu Archipelago). Mar Biol 102:329-339

Blanchot J, Rodier M (1996) Picophytoplankton abundance and biomass in the western tropical Pacific Ocean during 
the 1992 El Niño year: results from flow cytometry. DeepSea Res 43:877-895

Booth BC (1987) The use of autofluorescence for analyzing oceanic phytoplankton communities. Bot Mar 30:101-108

Campbell L, Liu H, Nolla HA, Vaulot D (1997) Annual variability of phytoplankton and bacteria in the subtropical North Pacific Ocean at Station ALOHA during the 1991-1994 ENSO event. Deep-Sea Res 44:167-192

Campbell L, Nolla HA, Vaulot D (1994) The importance of Prochlorococcus to community structure in the central North Pacific Ocean. Limnol Oceanogr 39:954-961

Capriulo GM, Sherr EB, Sherr BF (1991) Trophic behaviour and related community feeding activities of heterotrophic marine protists. In: Reid PC, Turley CM, Burkill PH (eds) Protozoa and their role in marine processes. NATO ASI Series Vol G25. Springer-Verlag, Berlin, p 219-265

Caron DA, Goldman JC, Andersen OK, Dennett MR (1985) Nutrient cycling in a microflagellate food chain: II. Population dynamics and carbon cycling. Mar Ecol Prog Ser 24:243-254

Caron DA, Lim EL, Miceli G, Waterbury JB, Valois FW (1991) Grazing and utilization of chroococcoid cyanobacteria and heterotrophic bacteria by protozoa in laboratory cultures and a coastal plankton community. Mar Ecol Prog Ser 76: $205-217$

Charpy L (1996) Phytoplankton biomass and production in two Tuamotu atoll lagoons (French Polynesia). Mar Ecol Prog Ser 145:133-142

Charpy L, Blanchot J (1998) Photosynthetic picoplankton in French Polynesia atoll lagoons: estimation of taxa contribution to biomass and production by flow cytometry. Mar Ecol Prog Ser 162:57-70

Charpy L, Charpy-Roubaud CJ (1991) Particulate organic matter fluxes in a Tuamotu atoll lagoon (French Polynesia). Mar Ecol Prog Ser 71:53-63

Charpy L, Dufour P, Garcia N (1997) Particulate organic matter in sixteen Tuamotu atoll lagoons (French Polynesia) Mar Ecol Prog Ser 151:55-65

Charpy-Roubaud CJ, Charpy L, Cremoux JL (1990) Nutrient budget of the lagoonal waters in an open central South Pacific atoll (Tikehau, Tuamotu, French Polynesia). Mar Biol 107:67-73

Cho BC, Azam F (1990) Biogeochemical significance of bacterial biomass in the ocean's eutrophic zone. Mar Ecol Prog Ser 63:253-259

Cole JJ, Findlay S, Pace ML (1988) Bacterial production in fresh and saltwater ecosystem: a cross-system overview. Mar Ecol Prog Ser 43:1-10

Fenchel $\mathrm{T}$ (1984) Suspended marine bacteria as a food source In: Fasham MJR (ed) Flows of energy and materials in marine ecosystems. Theory and practice, Vol 13. Plenum Press, New York, p 301-306

Ferrier-Pagès C, Gattuso JP (1998) Biomass, production and grazing rates of pico- and nanoplankton in coral reef waters (Miyako Island, Japan). Microb Ecol 35:46-57

Furnas MJ (1990) In situ growth rates of marine phytoplankton. Approaches to measurement, community and species growth rates. J Plankton Res 12:1117-1152

Gasol JM (1994) A framework for the assessment of top-down vs. bottom-up control of heterotrophic nanoflagellate abundance. Mar Ecol Prog Ser 113:291-300

González JM, Sherr EB, Sherr BF (1993) Differential feeding by marine flagellates on growing versus starving, and on motile versus non-motile, bacterial prey. Mar Ecol Prog Ser 102:257-267

Hansen PJ (1991) Dinophysis, a planktonic dinoflagellate genus which can act both as a prey and a predator of a ciliate. Mar Ecol Prog Ser 69:201-204
Hansen PJ (1992) Prey selection, feeding rates and growth dynamics of heterotrophic dinoflagellates with special emphasis on Gyrodinium spirale. Mar Biol 114:327-334

Haury LR, McGoan JA, Wiebe PH (1978) Patterns and processes in the time-space scales of plankton distributions. In: Steele JH (ed) Spatial patterns in plankton communities, Plenum Press, New York

Hopkinson CS Jr, Sherr BF, Ducklow HW (1987) Microbial regeneration of ammonium in the water column of Davies Reef, Australia. Mar Ecol Prog Ser 41:147-153

Kirchman DL (1993) Statistical analysis of direct counts of microbial abundance. In: Kemp PF, Sherr BF, Sherr EB, Cole JJ (eds) Aquatic microbial ecology. Lewis Publishers, Boca Raton, FL, p 117-119

Kuparinen J, Bjørnsen PK (1992) Bottom-up and top-down controls of the microbial food web in the Southern Ocean experiments with manipulated microcosms. Polar Biol 12: 189-195

Landry MR, Haas LW, Fagerness VL (1984) Dynamics of microbial plankton communities: experiments in Kaneohe Bay, Hawaii. Mar Ecol Prog Ser 16:127-133

Le Borgne R, Blanchot J, Charpy L. (1989) Zooplankton of Tikehau atoll (Tuamotu archipelago) and its relationship to particulate matter. Mar Biol 102:341-353

Lee S, Fuhrman JA (1987) Relationships between biovolume and biomass of naturally derived marine bacterioplankton. Appl Environ Microbiol 53:1298-1303

Lenhardt X (1991) Hydrodynamique des lagons d'atoll et d'île haute en Polynésie Française. ORSTOM Etudes et thèses, Paris

Lessard EJ, Swift E (1986) Dinoflagellates from the North Atlantic classified as autotrophic or heterotrophic by epifluorescence microscopy. J Plankton Res 8:1209-1215

Macisaac EA, Stockner JG (1993) Enumeration of phototrophic picoplankton by autofluorescence microscopy. In Kemp PF, Sherr BF, Sherr EB, Cole JJ (eds) Aquatic microbial ecology. Lewis Publishers, Boca Raton, FL, p 187-197

McManus GB, Okubo A (1991) On the use of surrogate food particles to measure protistan ingestion. Limnol Oceanogr 36:613-617

Pagès J, Torréton JP, Sempéré R (1997) Dissolved organic carbon in coral-reef lagoons, by high temperature catalytic oxidation and UV spectrometry. CR Acad Sci Paris Ser IIa Geochem 324:915-922

Pomeroy LR (1974) The ocean's food web, a changing paradigm. BioSci 24:499-504

Porter KG, Feig YS (1980) The use of DAPI for identifying and counting aquatic microflora. Limnol Oceanogr 25:943-948

Sanders RW, Caron DA, Berninger UG (1992) Relationships between bacteria and heterotrophic nanoplankton in marine and fresh waters: an inter-ecosystem comparison. Mar Ecol Prog Ser 86:1-14

Shapiro LP, Haugen EM, Carpenter EJ (1989) Occurrence and abundance of green-fluorescing dinoflagellates in surface waters of the Northwest Atlantic and Northeast Pacific oceans. J Phycol 25:189-191

Sherr BF, Sherr EB, Fallon RD (1987) Use of monodispersed, fluorescently labelled bacteria to estimate in situ protozoan bacterivory. Appl Environ Microbiol 53:958-965

Sherr BF, Sherr EB, McDaniel J (1992) Effect of protistan grazing on the frequency of dividing cells in bacterioplankton assemblages. Appl Environ Microbiol 58:2381-2385

Sherr BF, Sherr EB, Pedrós-Alió C (1989) Simultaneous measurement of bacterioplankton production and protozoan bacterivory in estuarine water. Mar Ecol Prog Ser 54:209-219

Sherr E, Sherr B (1988) Role of microbes in pelagic food webs: a revised concept. Limnol Oceanogr 33:1225-1227 
Sherr EB, Sherr BF (1993) Protistan grazing rates via uptake of fluorescently labeled prey. In: Kemp PF, Sherr BF, Sherr EB, Cole JJ (eds) Aquatic microbial ecology. Lewis Publishers, Boca Raton, FL, p 695-701

Sherr EB, Sherr BF, McDaniel J (1991) Clearance rates of $<6 \mu \mathrm{m}$ fluorescently labeled algae (FLA) by estuarine protozoa: potential grazing impact of flagellates and ciliates. Mar Ecol Prog Ser 69:81-92

Sime-Ngando T, Juniper K, Vézina A (1992) Ciliated protozoan communities over Cobb Seamount: increase in biomass and spatial patchiness. Mar Ecol Prog Ser 89 : $37-51$

Solic M, Krstulovic N (1994) Role of predation in controlling bacterial and heterotrophic nanoflagellate standing stocks in the coastal Adriatic Sea: seasonal patterns. Mar Ecol Prog Ser 114:219-235

Sorokin Y (1994) Role of plankton in the turnover of organic matter on the Great Barrier Reef, Australia. Hydrobiologia $308: 35-44$

Steele JH (1991) Marine ecosystem dynamics: comparison of scales. Ecol Res 6:175-183

Stoecker DK, Capuzzo JM (1990) Predation on protozoa: its importance to zooplankton. J Plankton Res 12:891-908

Editorial responsibility: John Dolan,

Villefranche-sur-Mer, France
Stoecker DK, Taniguchi A, Michaelis AE (1989) Abundance of autotrophic, mixotrophic and heterotrophic plankton ciliates in shelf and slope waters. Mar Ecol Prog Ser 50 $241-254$

Strom SL, Buskey EJ (1993) Feeding, growth, and behavior of the thecate heterotrophic dinoflagellate Oblea rotunda Limnol Oceanogr 38:965-977

Suttle CA (1994) The significance of viruses to mortality in aquatic microbial community. Microb Ecol 28:237-243

Torréton JP, Dufour P (1996a) Bacterioplankton production determined by DNA synthesis, protein synthesis and frequency of dividing cells in Tuamotu atoll lagoons and surrounding ocean. Microb Ecol 32:185-202

Torréton JP, Dufour P (1996b) Temporal and spatial stability of bacterioplankton biomass and productivity in an atoll lagoon. Aquat Microb Ecol 11:251-261

Verity PG (1991) Measurement and simulation of prey uptake by marine planktonic ciliates fed plastidic and aplastidic nanoplankton. Limnol Oceanogr 36:729-750

Yoshinaga I, Fukami K, Ishida Y (1991) Comparison of DNA and protein synthesis growth rates of bacterial assemblages between coral reef waters and pelagic waters in tropical ocean. Mar Ecol Prog Ser 76:167-174

Submitted: December 1, 1997; Accepted: May 11, 1998

Proofs received from author(s): September 18, 1998 